\title{
Wykorzystanie pirolitycznej chromatografii gazowej do określania składu produktów symulowanego procesu generowania węglowodorów
}

\begin{abstract}
W artykule przedstawiono elementy optymalizacji nowej procedury badawczej, jaką jest pirolityczna chromatografia gazowa (Py-GC), która może zostać wykorzystana do określania typu związków organicznych generowanych przez różnego rodzaju skały macierzyste. Nowo opracowana metodyka badawcza doskonale nadaje się do badań różnego typu próbek geologicznych, m.in. rdzeni skalnych, kerogenu, jak również ekstraktów bitumicznych czy frakcji asfaltenowych, wyekstrahowanych ze skał macierzystych. W ramach badań laboratoryjnych wykonano optymalizację warunków analizy chromatograficznej i procesu pirolizy (temperatury i czasu) oraz skontrolowano wpływ wybranych parametrów na powtarzalność metody.
\end{abstract}

Słowa kluczowe: Py-GC, piroliza, chromatografia gazowa, generowanie węglowodorów, skała macierzysta, kerogen.

\section{Using pyrolysis gas chromatography (Py-GC) to determine the products composition of the simulated generation process of hydrocarbons}

\begin{abstract}
This article presents elements for the optimization of new research methodology, such as pyrolysis gas chromatography (Py-GC) that can be used to determine the type of organic compounds generated by various source rocks. Newly developed research methodology is well suited for various types of geological samples analysis (such as: cores, kerogen, as well as bitumen or asphaltene fraction, extracted from source rocks). In the laboratory tests the optimization of conditions for chromatographic analysis and pyrolysis process was performed (temperature and time) and the influence of selected parameters on the method's repeatability was checked.
\end{abstract}

Key words: Py-GC, pyrolysis, gas chromatography, hydrocarbons generation, source rock, kerogen.

\section{Wstęp}

Proces wysokotemperaturowej pirolizy sprzężonej z chromatografią gazową (Py-GC) jest stosowany między innymi w badaniach geochemicznych dla charakterystyki skał macierzystych, kerogenu, ekstraktów bitumicznych, asfaltenów, węgli i rop naftowych. Eksperymenty symulowanego przeobrażenia odgrywają ważną rolę $\mathrm{w}$ demonstrowaniu kinetyki procesów generowania węglowodorów z kerogenu. Wyniki uzyskane $\mathrm{z}$ analizy Py-GC pomagają $\mathrm{w}$ zrozumieniu zagadnień generowania i ekspulsji węglowodorów w pracach związanych z poszukiwaniem ropy naftowej.

Układ pirolitycznej chromatografii gazowej znajduje zastosowanie w geochemii naftowej do szybkiego oszacowania potencjału węglowodorowego skał macierzystych. Wykorzystywane powszechnie w geochemii naftowej techniki analityczne, w tym Rock-Eval, petrologia organiczna, analiza elementarna i ekstrakcja rozpuszczalnikami organicznymi, dostarczają informacji o zasobności w substancję organiczną, typie genetycznym i stopniu dojrzałości termicznej [1]. Dzięki eksperymentom pirolitycznym można zdobyć informacje nie tylko o strukturze kerogenu, ale także o kierunku zachodzących reakcji (pierwotne produkty mogą być transformowane do lżejszych węglowodorów) oraz o zanieczyszczeniach spowodowanych przez migrujące węglowodory lub dodatki do płynów wiertniczych. 
Tradycyjnie kerogen może być scharakteryzowany na podstawie przeprowadzonych badań fizykochemicznych i petrologicznych, co daje wstępne oszacowanie jego jakości pod względem generacyjnym [7].

Dwa główne czynniki kontrolujące potencjał węglowodorowy skał macierzystych na dowolnym etapie dojrzałości termicznej to:

- obecność frakcji osadu zawierającego takie struktury związków organicznych, które mają zdolność generowania węglowodorów,

- wydajność ekspulsji związków ropnych ze skał macierzystych.

Poziom przeobrażenia materii organicznej w osadzie odzwierciedla aktualny stan postępujących reakcji na drodze konwersji organicznej materii do ropy i gazu oraz wysokotemperaturowego metanu.

Istnieją dwa następujące po sobie procesy kontrolujące ekspulsję wygenerowanych węglowodorów ze skał macierzystych do skał nośnych / skał zbiornikowych [4]:

1) uwolnienie wygenerowanych węglowodorów z kerogenu;

2) przemieszczanie (migracja) tych węglowodorów w obrębie skały macierzystej.

Tezy tej dowiedli liczni naukowcy, wykazując tym samym, że uwolnienie ciekłych węglowodorów z kerogenu jest ważnym czynnikiem limitującym i po ich uwolnieniu pierwotna migracja (przemieszczanie węglowodorów w obrębie skały źródłowej) jest nieistotna [6]. Uwalnianie ciekłych węglowodorów z kerogenu jest kontrolowane przez ich absorpcję/adsorpcję wewnątrz i/lub na powierzchni kerogenu i dyfuzję tych węglowodorów za pośrednictwem kerogenu. Natomiast efektywność uwalniania ropy jest kontrolowana głównie poprzez ilość i potencjał generacyjny kerogenu [9].

Badania asfaltenów oraz kerogenu skały macierzystej są niezmiernie ważnym zagadnieniem $\mathrm{w}$ geochemii naftowej. W licznych badaniach naukowych udowodniono, że asfalteny mogą być związkami pośrednimi w trakcie generowania surowej ropy i mają zbliżone właściwości składu, który odziedziczyły z macierzystego kerogenu w wyniku termicznego krakowania jego wielkocząsteczkowej struktury [3].

Szeroko rozumiana piroliza może również znaleźć zastosowanie w określaniu kinetyki reakcji, której znajomość jest niezbędna w trakcie modelowania procesów generowania węglowodorów [8]. Należy zwrócić uwagę, że w celu poznania czasu występowania procesów generacji ropy naftowej ze skał macierzystych zachodzi konieczność uwzględnienia termicznej historii basenu i właściwości kinetycznych kerogenu zawartego w skałach macierzystych [10]. Aby tego dokonać, można zastosować następujące narzędzia badawcze: pirolizę sprzężoną z chromatografią gazową (Py-GC) i Py-GC połączoną ze spektrometrią masową (Py-GC-MS), która to daje jeszcze większe możliwości poznawcze zachodzących procesów generacyjnych. Parametry kinetyczne z całą pewnością zależą od budowy strukturalnej kerogenu, którą można odtworzyć poprzez wnikliwą analizę pirogramów.

Głównym celem badań było opracowanie i optymalizacja nowej metodyki badawczej służącej przede wszystkim do jakościowego i ilościowego zdefiniowania typu generowanych węglowodorów z konkretnych skał macierzystych. W przyszłości umożliwi to dalsze korelacje z poszczególnymi akumulacjami węglowodorów, a tym samym wskaże na związki genetyczne z odpowiednimi facjami skał macierzystych, co pomoże w określeniu kierunków migracji węglowodorów.

\section{Metodyka badań procesu wysokotemperaturowej pirolizy sprzężonej z kapilarną chromatografią gazową (Py-GC)}

Badanie procesu wysokotemperaturowej pirolizy zostało wykonane w Laboratorium Geochemii Nafty i Gazu - PIB z wykorzystaniem aparatury badawczej, takiej jak wielokanałowy pirolizer (Multi-Shot Pyrolyzer EGA/PY-3030D) firmy Frontier Laboratories sprzężony z chromatografem gazowym (GC-2010 Plus) firmy Shimadzu, wyposażonym w detektor płomieniowo-jonizacyjny (FID) (rysunek 1).

Wielkość próby badanej jest zróżnicowana - zależy od rodzaju próbki i powinna również być dostosowana do wymogów technicznych kolumny chromatograficznej, detektora oraz pirolizera. Najbardziej korzystne jest prowadzenie procesu pirolizy na małych ilościach próbki. W przypadku materiału bogatego w materię organiczną (np. kerogen, ekstrakt bitumiczny, frakcja asfaltenowa) są to wielkości

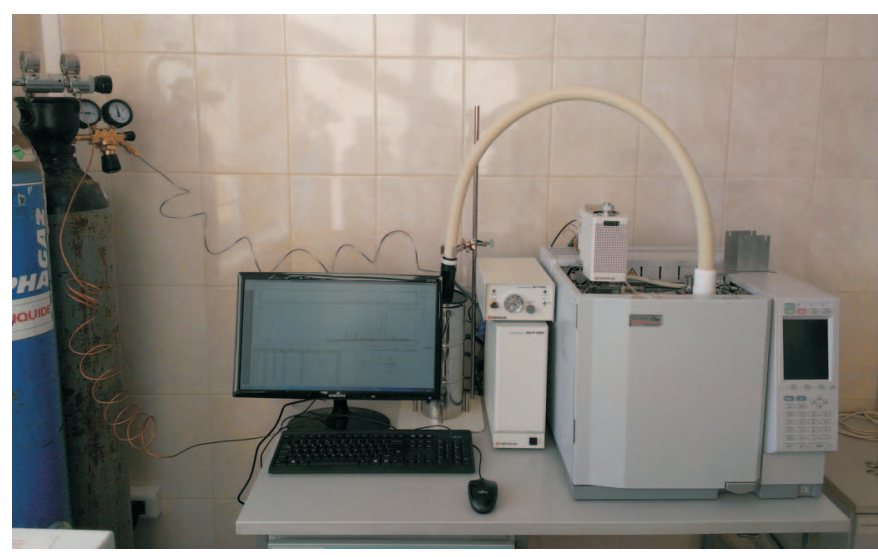

Rys. 1. Wielokanałowy pirolizer (Multi-Shot Pyrolyzer EGA/PY-3030D) firmy Frontier Laboratories sprzężony z chromatografem gazowym (GC-2010 Plus) firmy Shimadzu 
od 0,1 do 1,0 mg. Z kolei większe ilości próbki (rzędu kilku mg) mogą być poddane procesowi pirolizy, gdy mamy do czynienia z częściowym udziałem materii organicznej (np. próbka skalna). W tym przypadku zalecane jest zmielenie próbki do postaci drobnego proszku. Badana próbka rdzeniowa przed poddaniem jej analizie pirolitycznej została rozdrobniona w młynku agatowym do frakcji ziaren poniżej $0,02 \mathrm{~mm}$.

Po naważeniu odpowiedniej ilości próbki (w zależności od jej rodzaju: rozdrobniony rdzeń skalny - około $10 \mathrm{mg}$, kerogen - około $0,8 \mathrm{mg}$, ekstrakt bitumiczny - około 0,6 mg, frakcja asfaltenowa - około 0,3 mg) umieszczono ją w naczynku, a następnie przytwierdzono do próbnika. Próbnik wraz z próbką włożono do pirolizera. Przed wprowadzeniem próbki do pieca pirolitycznego wypłukano powietrze, które dostało się do komory pirolizera podczas jej dozowania. W tym celu należy zastosować odpowiednio długi czas przepłukiwania (około 2 minuty), aby martwa przestrzeń w próbniku zawierająca powietrze została całkowicie zastąpiona gazem obojętnym, takim jak hel. Następnie próbka pirolizowana jest w piecu pirolitycznym w atmosferze gazu obojętnego (helu) $\mathrm{w}$ programowanej temperaturze $600^{\circ} \mathrm{C} \mathrm{w}$ czasie 0,4 min. W trakcie procesu pirolizy zastosowano temperaturę interfejsu $250^{\circ} \mathrm{C}$ oraz wyposażenie dodatkowe: wymrażarkę MicroJet Cryo-Trap (MJT-1030Ex). Produkty termicznej destrukcji analizowanej próbki oznaczane są jakościowo przy użyciu chromatografu gazowego z detektorem FID.

Do przeprowadzenia analizy chromatograficznej zastosowano kolumnę kapilarną Ultra Alloy-5 o długości 30,0 m, średnicy wewnętrznej $0,25 \mathrm{~mm}$, grubości filmu $0,25 \mu \mathrm{m}$, połączoną z detektorem FID. Jako gazu nośnego użyto helu o stałej prędkości przepływu - 1,98 ml/min. Z kolei temperatura pracy chromatografu była programowana w różnych zakresach, co pozwoliło ostatecznie na dobór optymalnych warunków analizy próbek geologicznych. W związku z tym zastosowano gradient temperaturowy kolumny od $30^{\circ} \mathrm{C}$ do $360^{\circ} \mathrm{C}$ z narostem $10^{\circ} \mathrm{C} / \mathrm{min}$, temperaturę dozownika $250^{\circ} \mathrm{C}$, podział strumienia $\mathrm{w}$ stosunku 10:1 oraz temperaturę detektora FID $360^{\circ} \mathrm{C}$.

\section{Część doświadczalna - optymalizacja warunków procesu Py-GC}

\section{Optymalizacja warunków analizy chromatograficznej}

Optymalizacji parametrów metodyki służącej do oznaczeń chromatograficznych dokonano przy użyciu licznych wzorców n-alkanów. Do tego celu zastosowano wielokanałowy pirolizer sprzężony z chromatografem gazowym wyposażonym w detektor płomieniowo-jonizacyjny (FID). Temperatura pracy chromatografu była programowana w różnych zakresach, co pozwoliło ostatecznie na dobór optymalnych warunków analizy próbek geologicznych (przedstawione w opisie metodyki badawczej). Dobór programu temperaturowego kolumny nastąpił w taki sposób, aby rozdział poszczególnych składników był jak najlepszy, a wpływ czynników przeszkadzających jak najmniejszy.

Wybrane chromatogramy roztworów wzorcowych analizowanych w wyżej wymienionych warunkach obrazujące rozdział węglowodorów nasyconych przedstawiono na rysunkach 2-4.

\section{Optymalizacja temperatury pirolizy}

Optymalizację parametrów metodyki Py-GC przeprowadzono przy użyciu próbek kerogenu wyizolowanego z łupków menilitowych (pochodzących z jednej lokalizacji), stosując następujące warunki pracy pirolizera:

- gaz nośny: hel,

- temperatura interfejsu: $250^{\circ} \mathrm{C}$,

- wyposażenie dodatkowe: wymrażarka MicroJet Cryo -Trap (MJT-1030Ex).
Najbardziej korzystne parametry pirolizy (zarówno temperaturę, jak i czas) wyznaczono eksperymentalnie. W celu lepszego poznania procesu generowania węglowodorów badania pirolityczne prowadzono $\mathrm{w}$ temperaturach: $500^{\circ} \mathrm{C}$ (rysunek 5), $600^{\circ} \mathrm{C}$ (rysunek 6), $700^{\circ} \mathrm{C}$ (rysunek 7), $800^{\circ} \mathrm{C}$ (rysunek 8 ), $950^{\circ} \mathrm{C}$ (rysunek 9 ) oraz $1050^{\circ} \mathrm{C}$ (rysunek 10) przy zachowaniu stałego czasu pirolizy - 0,3 min.

Pirogramy analizowanego kerogenu (rysunki 5-10) ilustrują jakościową zmienność składu węglowodorowego produktów pirolizy. Z kolei ocenę ilościową na podstawie integracyjnej sumy dla wytypowanych przedziałów zebrano w tablicy 1 . Zmiana składu molekularnego węglowodorów ze wzrostem temperatury pirolizy wyraźnie wskazuje na pogłębiający się kraking uwalnianych pirolitycznie węglowodorów. Dodatkowo w wyższych temperaturach pirolizy następuje zanik informacji o typie genetycznym kerogenu, w związku z tym zdecydowano o wyborze temp. $600^{\circ} \mathrm{C}$ jako optymalnej do prowadzenia dalszych testów pirolitycznych.

\section{Optymalizacja czasu pirolizy}

Optymalizacji czasu pirolizy dokonano przy użyciu próbki kerogenu wyizolowanego z łupków menilitowych (podobnie jak w przypadku optymalizacji temperatury pirolizy). W celu lepszego poznania procesu generowania węglowodorów badania pirolityczne prowadzono w czasie: $0,2 \mathrm{~min}$ (rysunek 11), 0,3 min (rysunek 12), 0,4 min (rysunek 13) 


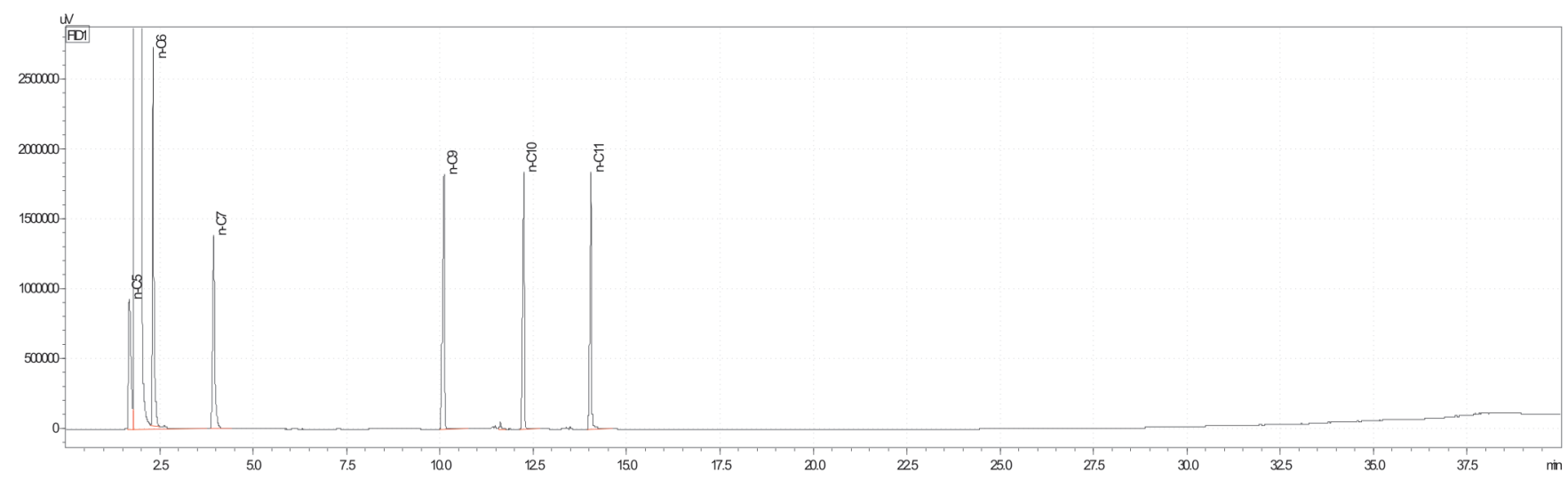

Rys. 2. Przykładowy chromatogram roztworu wzorcowego zawierającego w składzie: n-C5, n-C6, n-C7, n-C9, n-C10 oraz n-C11

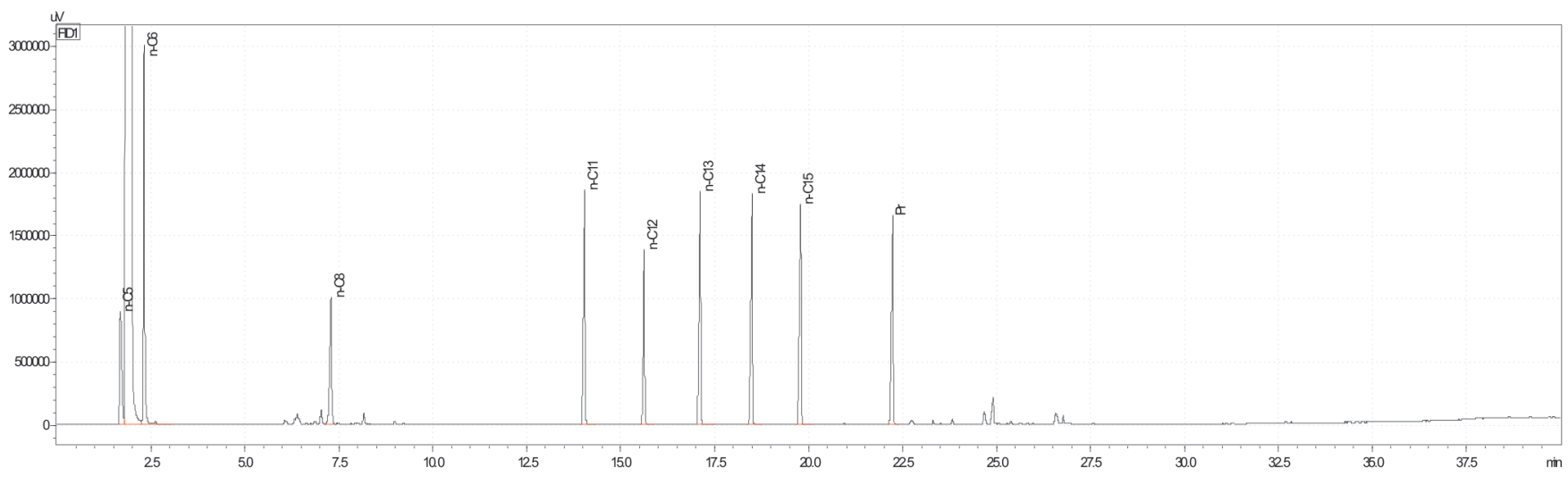

Rys. 3. Przykładowy chromatogram roztworu wzorcowego zawierającego w składzie: n-C5, n-C6, n-C8, n-C11, n-C12, $\mathrm{n}-\mathrm{C} 13, \mathrm{n}-\mathrm{C} 14, \mathrm{n}-\mathrm{C} 15$ oraz pristan

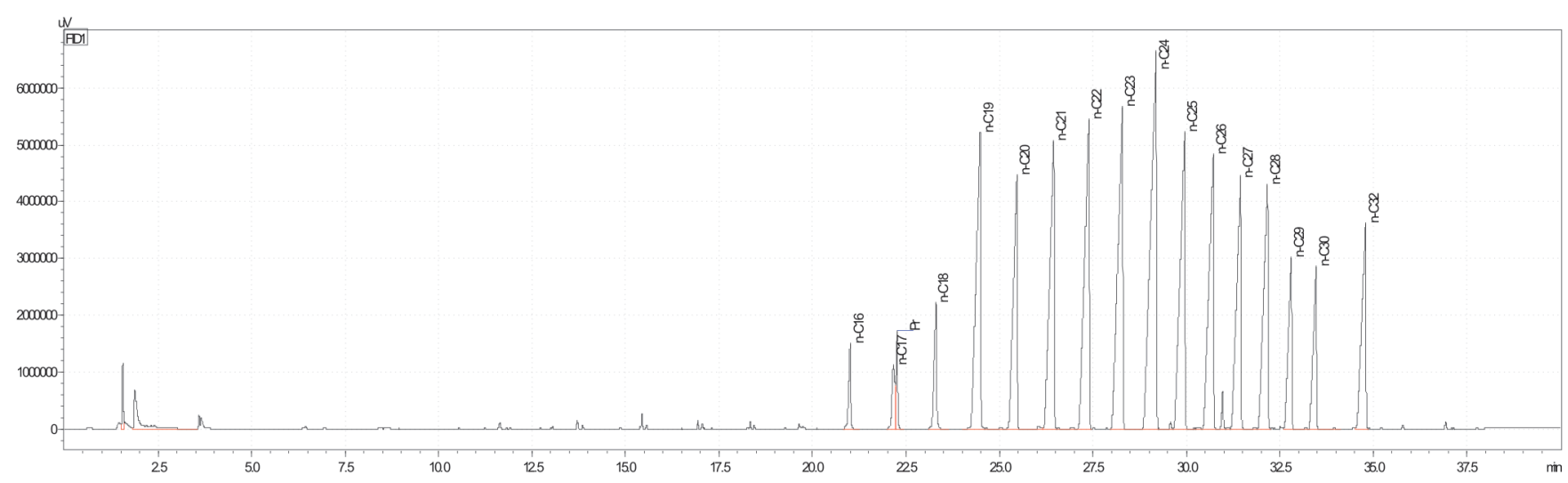

Rys. 4. Przykładowy chromatogram roztworu wzorcowego zawierającego w składzie: n-C16, n-C17, pristan, n-C18, n-C19, n-C20, n-C21, n-C22, n-C23, n-C24, n-C25, n-C26, n-C27, n-C28, n-C29, n-C30 oraz n-C32

oraz 1 min (rysunek 14) przy zachowaniu stałej temperatury pirolizy $-600^{\circ} \mathrm{C}$.

Na podstawie uzyskanych $\mathrm{w}$ trakcie analizy pirogramów (rysunki 11-14), jak również stosunków wygenerowanych węglowodorów podczas prowadzonego procesu (tablica 2) można zauważyć, że dobór najbardziej optymalnego czasu pirolizy (podobnie jak temperatury) ma istotne znaczenie. Zarówno 0,2 min, jak i 0,3 min to czas zbyt krótki, aby cała analizowana próbka została spirolizowana, uwalniając tym samym zbliżone ilości poszczególnych grup węglowodorowych. $\mathrm{Z}$ kolei badania prowadzone w czasie 0,4 min wykazały wysoką powtarzalność wyników analiz składu generowanych węglowodorów w porównaniu z czasem 1,0 min, wskazując tym samym, że czas 0,4 min jest w zupełności wystarczający i optymalny do wykonywania tego typu pirolizy. 


\section{NAFTA-GAZ}

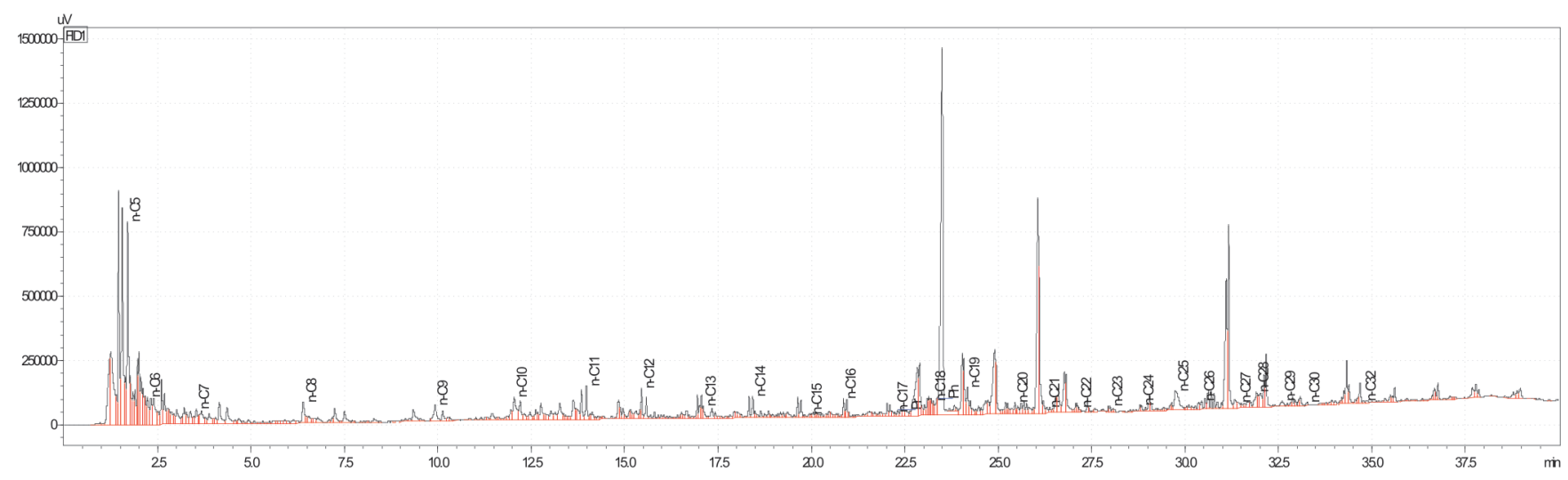

Rys. 5. Pirogram próbki kerogenu poddanej przez 0,3 min pirolizie w temperaturze $500^{\circ} \mathrm{C}$

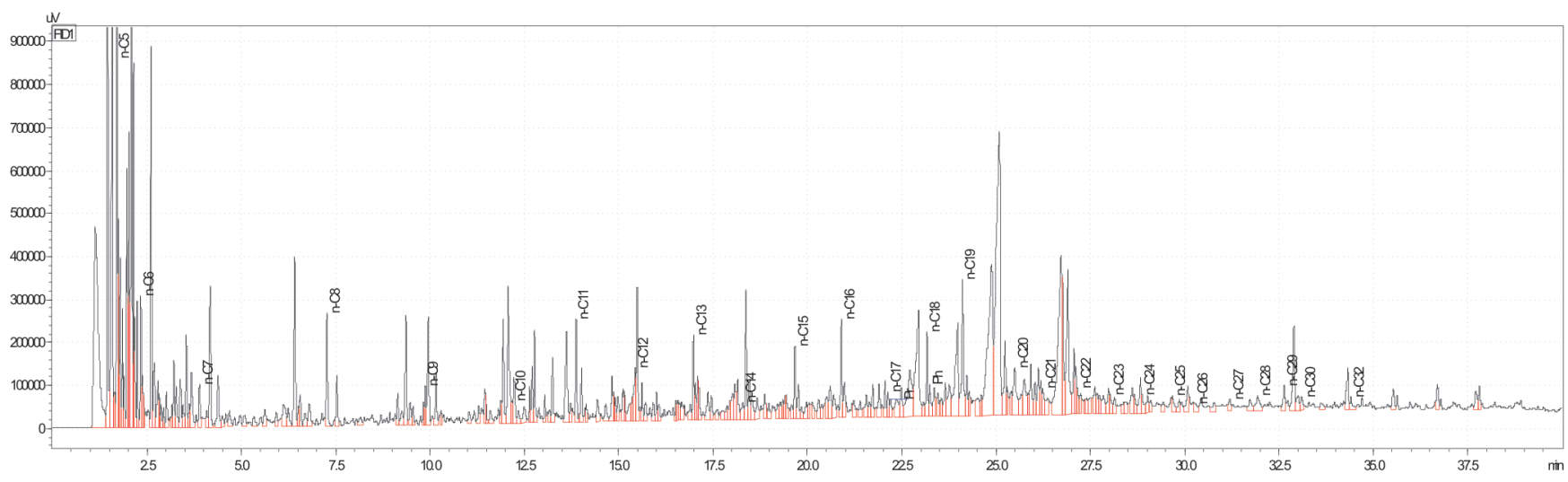

Rys. 6. Pirogram próbki kerogenu poddanej przez 0,3 min pirolizie w temperaturze $600^{\circ} \mathrm{C}$

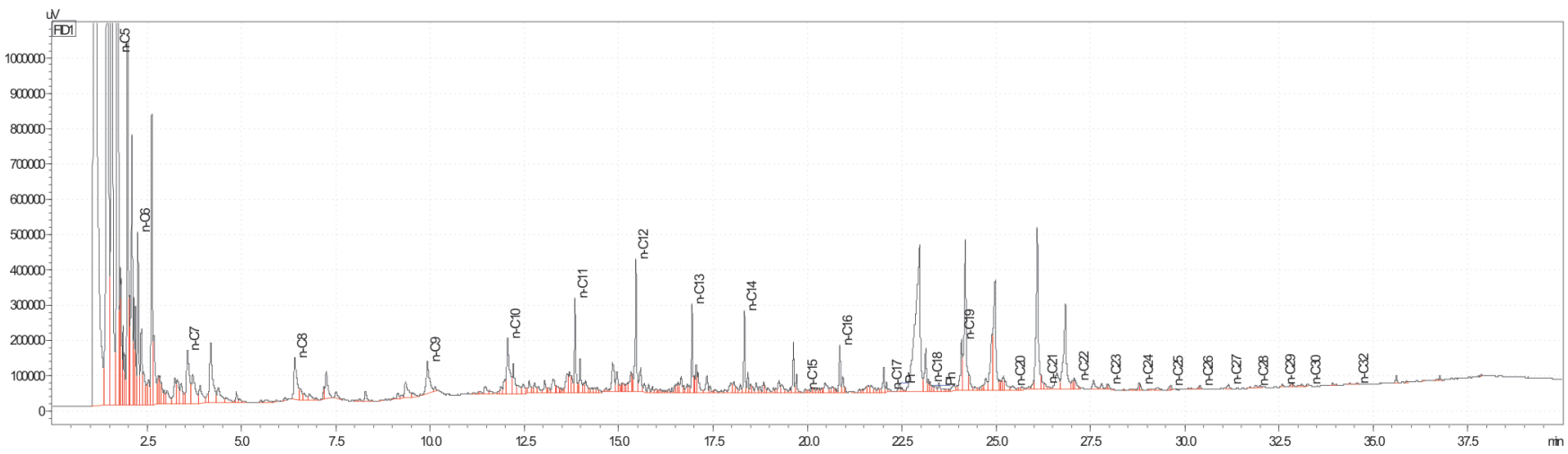

Rys. 7. Pirogram próbki kerogenu poddanej przez 0,3 min pirolizie w temperaturze $700^{\circ} \mathrm{C}$

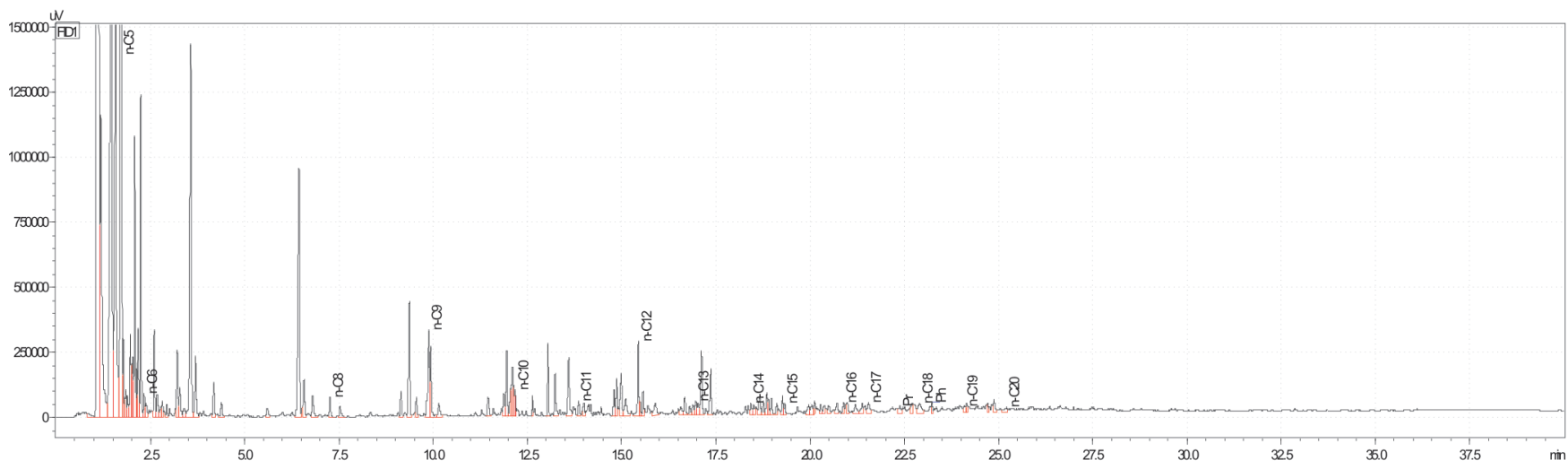

Rys. 8. Pirogram próbki kerogenu poddanej przez 0,3 min pirolizie w temperaturze $800^{\circ} \mathrm{C}$ 


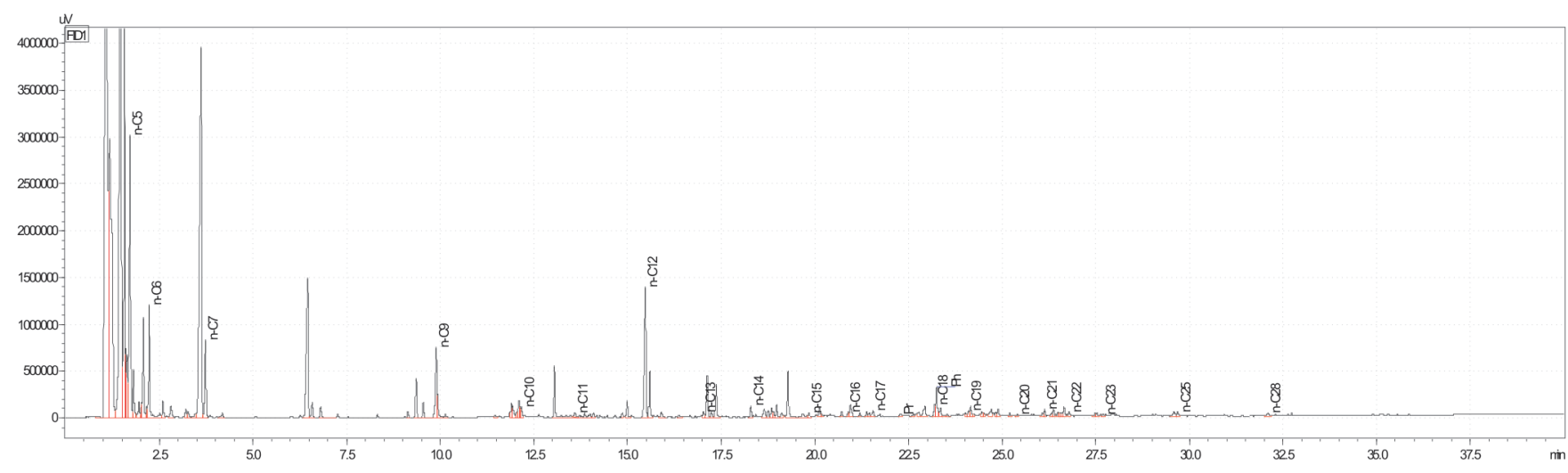

Rys. 9. Pirogram próbki kerogenu poddanej przez 0,3 min pirolizie w temperaturze $950^{\circ} \mathrm{C}$

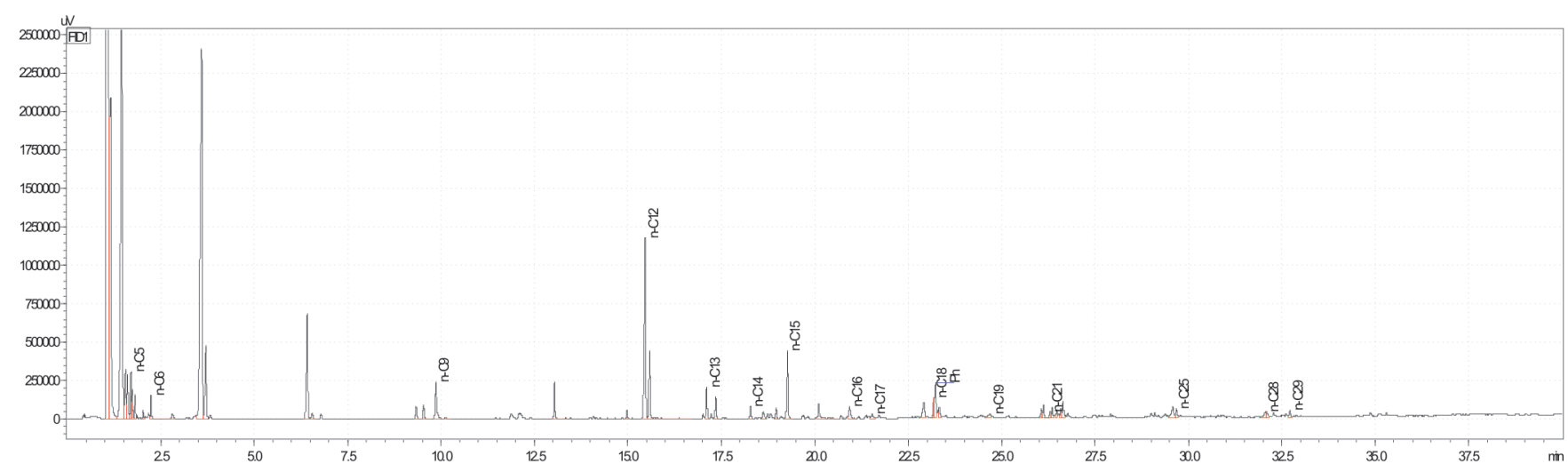

Rys. 10. Pirogram próbki kerogenu poddanej przez 0,3 min pirolizie $\mathrm{w}$ temperaturze $1050^{\circ} \mathrm{C}$

Tablica 1. Wyniki analizy pirolitycznej Py-GC wyizolowanego kerogenu przedstawiające skład produktów symulowanego procesu generowania węglowodorów w różnych temperaturach

\begin{tabular}{|c|c|c|c|}
\hline \multirow{2}{*}{$\begin{array}{c}\text { Temperatura } \\
{\left[{ }^{\circ} \mathrm{C}\right]}\end{array}$} & \multicolumn{3}{|c|}{ Skład węglowodorowy z Py-GC [\%] } \\
\cline { 2 - 4 } & $\mathrm{do}_{9}$ & $\mathrm{C}_{9}-\mathrm{C}_{15}$ & $\mathrm{C}_{15+}$ \\
\hline 500 & 32,48 & 15,50 & 52,02 \\
\hline 600 & 42,47 & 18,45 & 39,08 \\
\hline 700 & 69,92 & 12,96 & 17,12 \\
\hline 800 & 82,93 & 13,65 & 3,43 \\
\hline 950 & 83,76 & 10,62 & 5,61 \\
\hline 1050 & 82,64 & 9,65 & 7,71 \\
\hline
\end{tabular}

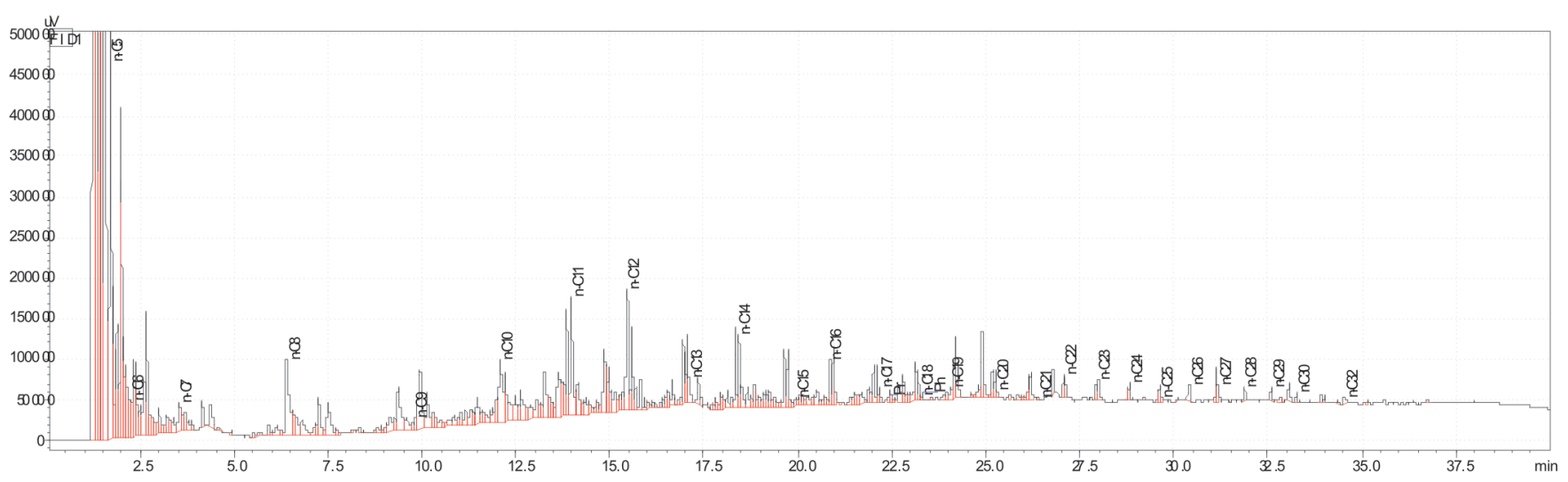

Rys. 11. Pirogram próbki kerogenu poddanej przez 0,2 min pirolizie w temperaturze $600^{\circ} \mathrm{C}$ 


\section{NAFTA-GAZ}

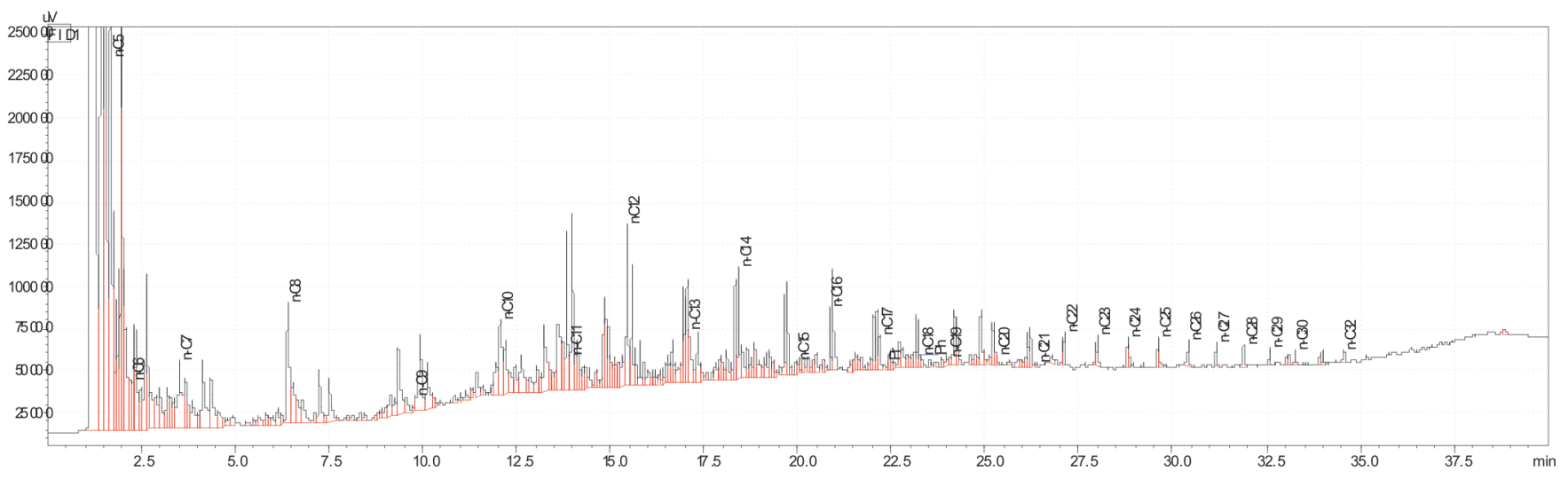

Rys. 12. Pirogram próbki kerogenu poddanej przez $0,3 \mathrm{~min}$ pirolizie w temperaturze $600^{\circ} \mathrm{C}$

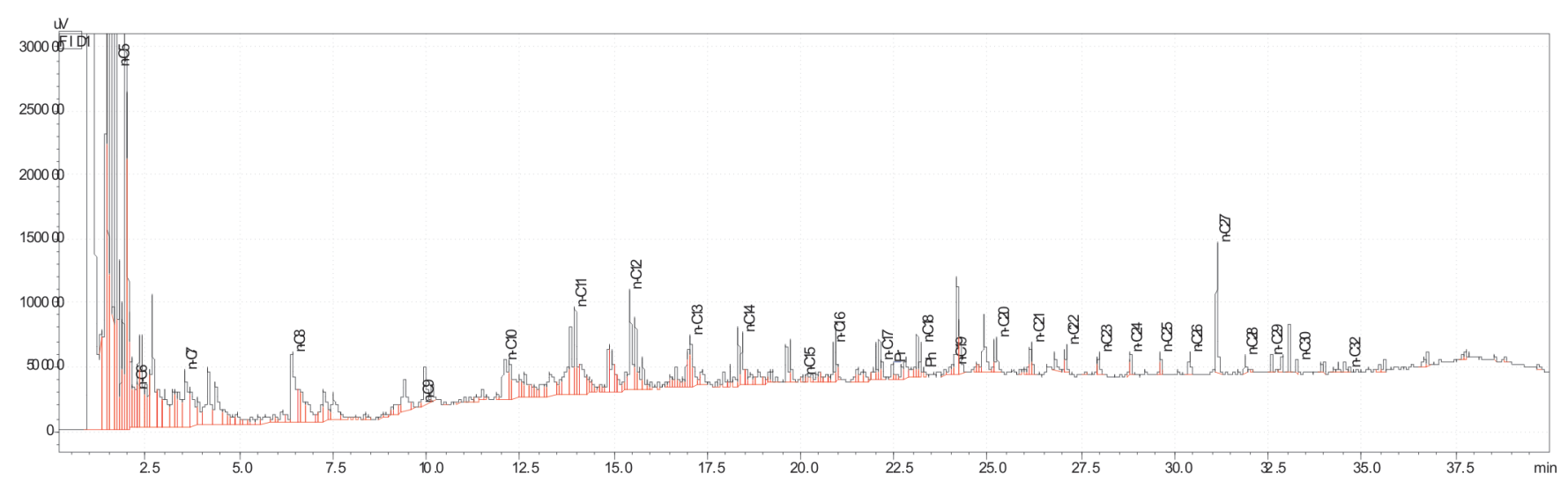

Rys. 13. Pirogram próbki kerogenu poddanej przez 0,4 min pirolizie w temperaturze $600^{\circ} \mathrm{C}$

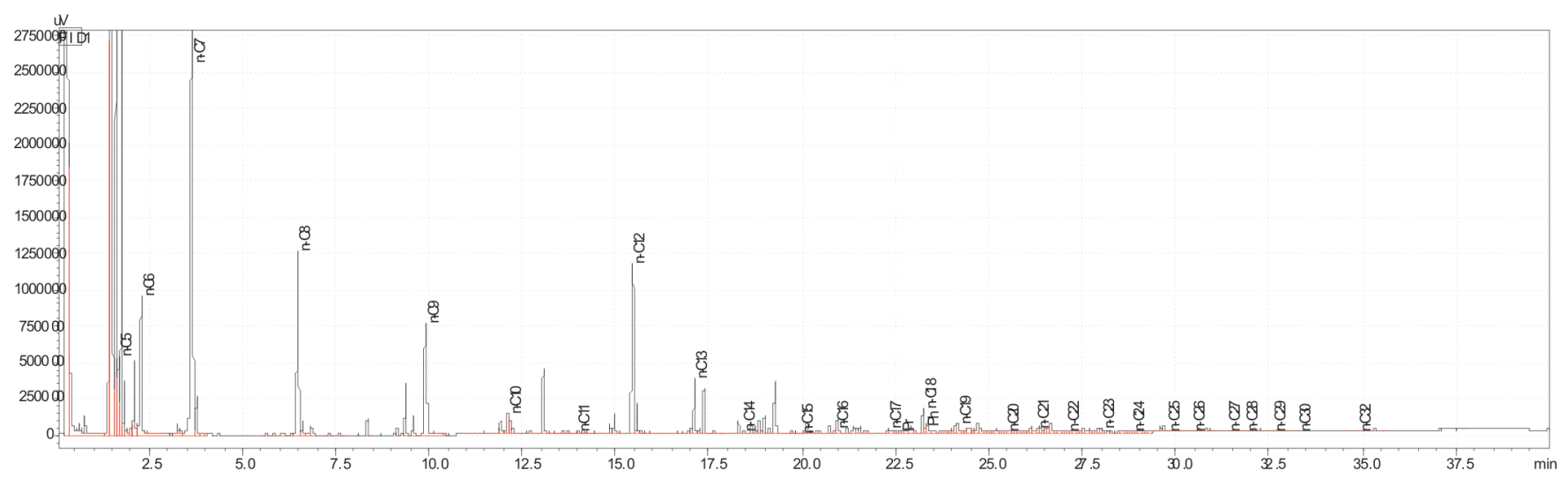

Rys. 14. Pirogram próbki kerogenu poddanej przez 1,0 min pirolizie w temperaturze $600^{\circ} \mathrm{C}$

Tablica 2. Wyniki analizy pirolitycznej Py-GC wyizolowanego kerogenu przedstawiające skład produktów symulowanego procesu generowania węglowodorów w różnym czasie pirolizy

\begin{tabular}{|c|c|c|c|}
\hline \multirow{2}{*}{$\begin{array}{c}\text { Czas } \\
{[\mathrm{min}]}\end{array}$} & \multicolumn{3}{|c|}{ Skład węglowodorowy z Py-GC [\%] } \\
\cline { 2 - 4 } & do $\mathrm{C}_{9}$ & $\mathrm{C}_{9}-\mathrm{C}_{15}$ & $\mathrm{C}_{15+}$ \\
\hline 0,2 & 64,09 & 25,73 & 10,18 \\
\hline 0,3 & 67,94 & 23,25 & 8,81 \\
\hline 0,4 & 71,75 & 17,30 & 10,95 \\
\hline 1,0 & 71,46 & 17,09 & 11,45 \\
\hline
\end{tabular}




\section{Powtarzalność procesu pirolitycznej chromatografii gazowej (Py-GC)}

W celu sprawdzenia precyzji (powtarzalności) nowo opracowanej metodyki badawczej wykonano sześć niezależnych pomiarów wyizolowanego kerogenu (pomiarów dokonywał ten sam analityk), a następnie określono rozrzut uzyskanych wyników wokół wartości średniej na podstawie wartości odchylenia standardowego.

Precyzja metody analitycznej wyraża zgodność pomiędzy kilkoma seriami pomiarów otrzymanych dla tej samej jednorodnej próby [2]. Precyzja może być rozważana jako: - precyzja metody, powtarzalność,

- precyzja pośrednia - testy w obrębie jednego laboratorium, - odtwarzalność - testy międzylaboratoryjne.

Zakłada się, że precyzja metodyki, czyli zgodność pomiędzy niezależnymi wynikami uzyskanymi w trakcie analizy danej próbki z zastosowaniem opisanej metodyki analitycznej, obliczona jako współczynnik zmienności (CV), nie powinna przekraczać 15\% dla oznaczeń zawartości składników na poziomie śladowym [5].

Na podstawie przeprowadzonego testu powtarzalności nowo opracowanej metodyki badawczej można formułować tezę, iż analizowany kerogen uwolnił w trakcie pirolizy około $70 \%$ węglowodorów lekkich o łańcuchach od $\mathrm{C}_{1}$ do $\mathrm{C}_{8}$, około $18 \%$ węglowodorów o łańcuchach w przedziale od $\mathrm{C}_{9}$ do $\mathrm{C}_{15}$ i około $12 \%$ węglowodorów o łańcuchach powyżej $\mathrm{C}_{15}$.

Kryteria akceptacji dla precyzji metody zostały spełnione. Otrzymane wyniki dla sześciu niezależnych pomiarów próbki kerogenu wykonanych przez danego analityka świadczą o satysfakcjonującej powtarzalności walidowanej metodyki: współczynniki zmienności dla poszczególnych składników nie przekroczyły 15\% i został spełniony test Deana Dixona dla poziomu ufności $95 \%$.

Tablica 3. Wyniki testu powtarzalności procesu pirolizy dla próbki wyizolowanego kerogenu

\begin{tabular}{|l|c|c|c|}
\hline \multirow{2}{*}{ Pomiar } & \multicolumn{3}{|c|}{ Skład węglowodorowy z Py-GC [\%] } \\
\cline { 2 - 4 } & do $\mathrm{C}_{9}$ & $\mathrm{C}_{9}-\mathrm{C}_{15}$ & $\mathrm{C}_{15+}$ \\
\hline 1 & 71,75 & 17,30 & 10,95 \\
\hline 2 & 68,27 & 19,37 & 12,36 \\
\hline 3 & 70,01 & 17,43 & 12,57 \\
\hline 4 & 72,04 & 18,04 & 9,92 \\
\hline 5 & 66,81 & 19,20 & 13,99 \\
\hline 6 & 70,82 & 15,59 & 13,59 \\
\hline Średnia [\%] & 69,95 & 17,82 & 12,23 \\
\hline Maks. [\%] & 72,04 & 19,37 & 13,99 \\
\hline Min. [\%] & 66,81 & 15,59 & 9,92 \\
\hline SD & 2,05 & 1,40 & 1,55 \\
\hline CV [\%] & 2,93 & 7,83 & 12,71 \\
\hline
\end{tabular}

\section{Podsumowanie}

W niniejszej pracy podjęto się zadania opracowania i zoptymalizowania warunków nowej procedury badawczej, która może zostać wykorzystana do określania typu związków organicznych generowanych przez różnego rodzaju skały macierzyste. Zadanie to zostało wykonane w Laboratorium Geochemii Nafty i Gazu - PIB przy użyciu wielokanałowego pirolizera (Multi-Shot Pyrolyzer EGA/PY-3030D) firmy Frontier Laboratories sprzężonego z chromatografem gazowym (GC-2010 Plus) firmy Shimadzu.

Badane próbki zostały poddane eksperymentalnej pirolizie wysokotemperaturowej sprzężonej z kapilarną chromatografią gazową i studiowano je pod kątem zawartości trzech grup węglowodorowych, określając tym samym potencjalne możliwości generacyjne danej skały. Analizę pirolityczną we wszystkich przypadkach traktowano jako narzędzie służące do klasyfikacji skał macierzystych, identyfikowanych klasycznymi metodami analizy geochemicznej.

Na podstawie wnikliwej analizy poszczególnych pirogramów pod kątem zarówno rodzaju, jak również ilości wygenerowanych grup węglowodorowych zdecydowano o wyborze temperatury $600^{\circ} \mathrm{C}$ oraz czasu 0,4 min jako warunków optymalnych do prowadzenia testów pirolitycznych. Dodatkowo w celu sprawdzenia precyzji nowo opracowanej metodyki badawczej wykonano sześć niezależnych pomiarów 
wyizolowanego kerogenu, udowadniając tym samym satysfakcjonującą powtarzalność procedury analitycznej. Został spełniony test Deana Dixona dla poziomu ufności 95\%, a współczynniki zmienności dla poszczególnych składników nie przekroczyły $15 \%$.

Otrzymane wyniki eksperymentalne świadczą nie tylko o dużej przydatności tego typu badań w pracach nad określaniem rzeczywistych produktów generowanych z poten- cjalnych skał macierzystych, ale i ukazują fakt, że szczegółowe informacje uzyskane na podstawie pirogramów mogą być wykorzystywane w pracach modelowania różnego typu basenów naftowych. Nowo opracowana metoda pirolitycznej chromatografii gazowej może dodatkowo zostać włączona w ciąg badań geochemicznych przeprowadzanych dla rozpoznania profili geologiczno-geochemicznych w pracach poszukiwawczych.

Prosimy cytować jako: Nafta-Gaz 2015, nr 10, s. 720-728

Artykuł nadesłano do Redakcji 21.11.2014 r. Zatwierdzono do druku 14.05.2015 r.

Artykuł powstał na podstawie pracy statutowej pt. Wykorzystanie pirolizy Py-GC do określania typu związów organicznych, generowanych z różnego rodzaju skat macierzystych - praca INiG - PIB na zlecenie MNiSW; numer zlecenia: 50/SG/2014, numer archiwalny: DK-4100-50/14.

\section{Literatura}

[1] Dembicki H., Horsfield B., Ho T. T. Y.: Source rock evaluation by Pyrolysis-Gas Chromatography. AAPG Bulletin 1983, vol. 67, no. 7, s. 1094-1103.

[2] Holewa J., Szlek M.: Wplyw parametrow metody analitycznej na powtarzalnosc wyznaczonych na jej podstawie wlasciwosci fizykochemicznych gazu, na przykladzie ciepla spalania. Nafta-Gaz 2014, nr 7, s. 439-443.

[3] Horsfield B., Curry D. J., Bohacs K., Littke R., Rullkötter J., Schenk H. J., Radke M., Schaefer R. G., Carroll A. R., Isaksen G., Witte E. G.: Organic geochemistry of freshwater and alkaline lacustrine sediments in the Green River Formation of the Washakie Basin, Wyoming, U.S.A. Organic Geochemistry 1994, vol. 22, issues 3-5, s. 415-440.

[4] Inan S., Yalcin M. N., Mann U.: Expulsion of oil from petroleum source rocks: inferences from pyrolysis of samples of unconventional grain size. Organic Geochemistry 1998, vol. 29, s. 45-61.

[5] Jakubowska M.: Walidacja metod analitycznych. Prezentacja Katedry Chemii Analitycznej, Wydział Inżynierii Materiałowej i Ceramiki, Akademia Górniczo-Hutnicza.

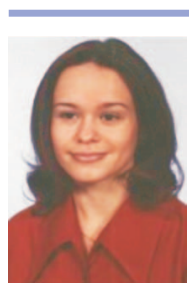

Mgr Małgorzata KANIA

Asystent w Zakładzie Geologii i Geochemii. Instytut Nafty i Gazu - Państwowy Instytut Badawczy ul. Lubicz 25 A

31-503 Kraków

E-mail: kaniam@inig.pl
[6] Mann U.: An integrated approach to the study of primary migration. [W:] Parnell J. (ed.): Geofluids: Origin, Migration and Evolution of Fluids in Sedimentary Basins. Geological Society Special Publication 1994, no. 78, s. 233-260.

[7] Matyasik I.: Piroliza lupkow menilitowych pobranych z odsloniec powierzchniowych $w$ rozpoznaniu generacji weglowodorow. Praca statutowa IGNiG 2003 nr 1/SG.

[8] Matyasik I., Sloczynski T.: Niekonwencjonalne zloza gazushale gas. Nafta-Gaz 2010, nr 3, s. 167-177.

[9] Pepper A. S., Corvi P. J.: Simple kinetic models of petroleum formation. III. Modeling an open system. Marine and Petroleum Geology 1995, vol. 12, no. 4, s. 417-452.

[10] Tegelaar E. W., Noble A. R.: Kinetics of hydrocarbon generation as function of the molecular structure of kerogen as revealed by pyrolysis-gas chromatography. Organic Geochemistry 1994, vol. 22, no. 3-5, s. 543-574.

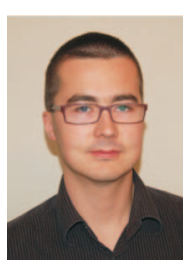

Mgr inż. Marek JANIGA

Asystent w Zakładzie Geologii i Geochemii.

Instytut Nafty i Gazu - Państwowy Instytut Badawczy ul. Lubicz 25 A

31-503 Kraków

E-mail: marek.janiga@inig.pl 